\title{
UPS Supported By Fuel Cell and Micro Turbine Energy System Based On Buck-Boost Converter for Telecom Industry
}

\author{
Mr. R.Madhan Mohan, Mr. K.Harinath Reddy, S.Suresh Babu, \\ M. Tech., Assistant Professor, Annamacharya Institute of Technology \& Sciences, Rajampet, India. \\ M. Tech., Assistant Professor, Annamacharya Institute of Technology \& Sciences, Rajampet, India. \\ M.Tech student, Annamacharya Institute of Technology \& Sciences, Rajampet, India.
}

\begin{abstract}
Typically, telecom power systems are connected to grid and diesel generator. This paper represents a new telecom power system using local micro-sources (fuel cell and micro-turbine). Some benefits of this system are effectively eliminating batteries, diesel generator and automatic transfer switch. In this paper, a new multiple input buck-boost converter is utilized as an interface between the micro-sources and the DC bus. Peak current mode control is used to control the current of fuel cell while voltage mode control is used to regulate the output voltage. A model for Proton Exchange Membrane Fuel Cell (PEM FC) and Micro-Turbine (MT) along with their subcomponents and internal controls are presented. Furthermore, the parallel operation of FC and MT using the proposed multiple input DC/DC converter is investigated. In addition, the dynamic response of the system to the dynamic behavior of the load is analyzed.
\end{abstract}

Keywords: - Telecom power system, multiple input converters, power system architecture, fuel cell model, micro-turbine model.

\section{INTRODUCTION}

Conventional telecommunication power systems are composed of grid, diesel generator, batteries, and an automatic transfer switch. These systems use AC bus as the main bus and connect the grid and diesel generator through transfer switch to the main bus. Most telecommunication systems use 24, 48, or 60V DC power plants that have several hours (between 2 to 8 hours) of battery backup system [1]. In these systems, inverters or Uninterruptable Power Supply (UPS) are utilized to supply the AC power from utility grid and diesel generator. The main goal of utilizing diesel generator is to provide uninterrupted power during long utility outages. During the power outage, power is temporarily supplied to the critical loads through batteries, and the automatic transfer switch will switch to diesel generator. This conventional system is relied on the diesel generator and batteries to provide uninterruptable service during long power outage. A conventional telecommunication power system is shown in Fig. 1. A typical telecommunication system has four different types of loads; AC non-critical loads, AC critical loads, AC ultra-critical loads, and DC critical loads [1].

The AC non-critical loads can survive during the power outage and they do not need any backup systems such as UPS or diesel generator. Typically, these loads are connected directly to the utility grid. The AC critical loads need to be backed up by diesel generator; however they do not need to be fed during short period of outages. These loads do not need backup systems through UPS or batteries. One example of these loads is air conditioning system. The AC ultra-critical loads need redundant uninterruptable power supply with at least 30 minutes of battery backup for the power outages of more than $3 \mathrm{~ms}$. some examples of these loads are network equipments and computers. The DC critical loads are connected to a DC bus through redundant rectifiers. These loads need the battery backup time of 2 to 8 hours. An example of these loads is switching equipments [1].

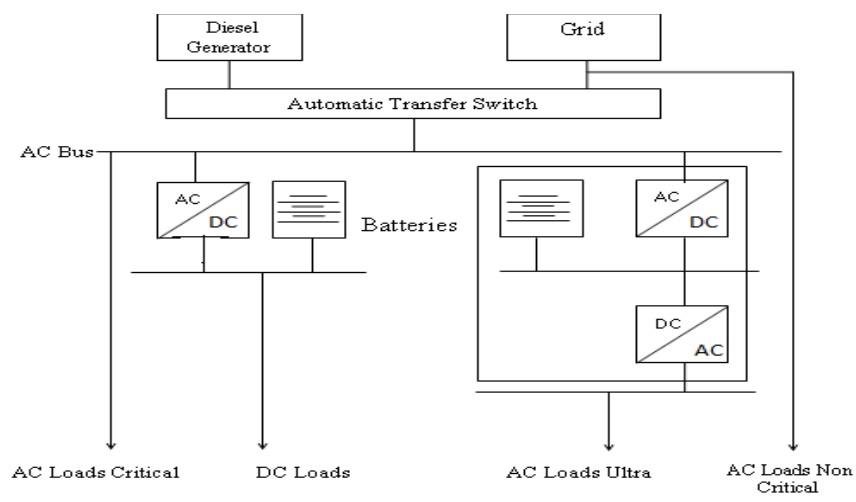

Fig.1.Conventional telecommunication power plant 
Although it is proven that the telecom power system in Fig.1 is a reliable telecommunication power plant, there are some drawbacks in this system [1]:

- The automatic transfer switch is a single point of failure in the system.

- While diesel generators are reliable if they equipped with two starters, they require frequent and costly maintenance. Besides, diesel generators are source of pollution and noise.

- A battery bank with long backup time requires space and considering replacement and maintenance, battery banks are one of the most expensive equipments in telecommunication systems.

Battery banks typically occupy a large area and they need to be replaced every 5years [2].Considering maintenance, replacement cost, and the area that battery bank occupies.

There are many different methods that try to address these issues and replace the diesel generator and reduce or eliminate the battery bank. The authors of [I] proposed a method using micro-turbine instead of diesel generator and reducing battery reserve time. In this method battery reserve time is reduced to 10 minutes. The main reason for 10 minutes battery reserve time is to provide the capability to restarting micro-turbine three times in the case that starting process fails. The benefit of this architecture is eliminating the diesel generator and automatic transfer switch. Battery reserve time is reduced to 10 minutes. The drawbacks are that the main source of power for this system is utility grid and still the system relies on battery bank.

In [3], ultra-capacitors are used instead of batteries. Although this system effectively eliminates the battery, it still needs to rely on diesel generator during long power outage. In [4], ultra-capacitors and fuel cells are used instead of batteries and diesel generator, respectively. The main benefit of this system is eliminating batteries completely. However, this system uses ultra-capacitors and fuel cell only as a backup system which can be considered as a drawback. Since fuel cells are rather expensive right now, it needs great time for pay back investment. Moreover, energy densities of ultra-capacitors are lower in compare to that of batteries. Thus, more ultra-capacitors banks are needed in order to provide sustained power supply for longer periods. Microturbine and fuel cell are coupled to achieve higher efficiency for electrical power generation in [6].

\section{PROPOSED ARCHITECTURE}

The proposed system in this paper uses micro-sources such as Micro-Turbine (MT) and Fuel Cell (FC). Most of micro-sources have a large response time which is in the order of seconds or minutes. In order to compensate for their slow response time, some sort of energy storage device with fast response time such as Ultra-Capacitor (UC) is needed. The UC needs to store power for only a few minutes. Some benefits of the UC are their wide range of operating temperature, long life, and superior performance [3]. Proposed architecture is shown in Fig. 2.

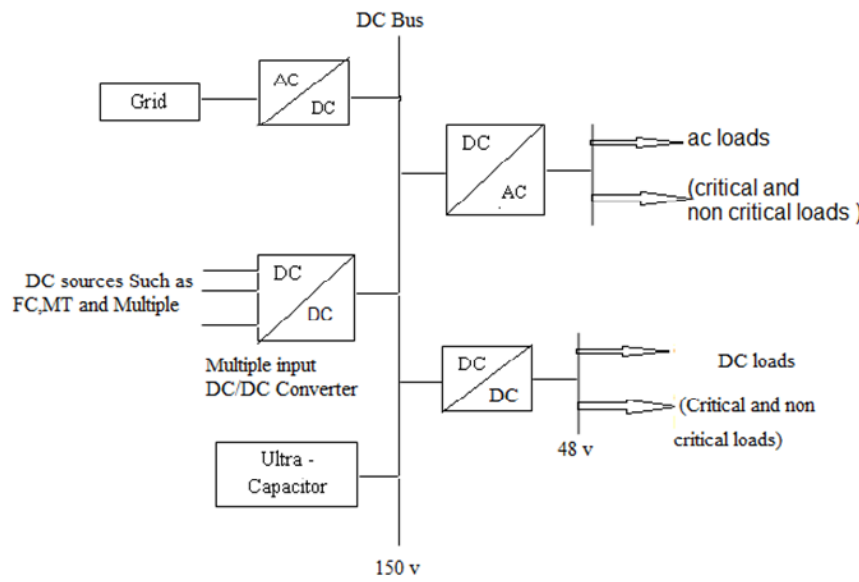

Fig.2.Proposed telecommunication power plant

In this system, not only micro-sources are used as backup systems during the power outage but also they are used for normal operation. This method reduces the investment payback time for micro-sources. Some benefits of the proposed architecture are eliminating the transfer switch, eliminating the diesel generator and eliminating the battery bank. Another benefit is that the critical and non-critical telecommunication loads are all connected to the main bus. This system supports all the load types (AC non-critical, AC critical, AC ultracritical, and DC critical) with high redundancy and high reliability such that none of these loads experience the power outage. This system can also be connected to grid through an ACIDC inverter for higher reliability and efficiency in the case of the micro-sources goes out of service.

In this system, each of the micro-sources can supply the necessary power for the load. Thus, even when one of the micro-sources goes out of service, the other micro-source can provide the load without any interruptions. The probability of unavailability of all MT, FC, and utility grid all at the same time is close to zero 
with the exception of natural disasters [I]. This architecture is very robust, reliable, and provides uninterrupted power to the load. This architecture can also be used in places that utility power is unavailable.

The proposed architecture for telecommunication power system in this paper uses DC bus is that most of the micro-sources have DC output voltage and they can easily be connected to this bus through a DC/DC converter. While micro-sources are connected to this bus through DC/DC converters, grid can also be connected through an $\mathrm{AC} / \mathrm{DC}$ rectifier. There are three different commonly used possible nominal voltages for this DC bus (48V, $150 \mathrm{~V}$, and $300 \mathrm{~V})$. In the conventional telecommunication systems, $48 \mathrm{~V}$ is used. For DC bus, $150 \mathrm{~V}$ is chosen since it has some advantages such as higher system efficiency, less conductor losses, lower system cost, lower rectifier cost, and less required copper over the conventional 48V [5]. Additionally, $150 \mathrm{~V}$ is already used in some traditional systems powering toll switches [5]. The $300 \mathrm{~V}$ is more suitable if there is a need to bidirectional power flow for utility grid [5].

The load in telecommunication system varies from $3 \mathrm{~kW}$ in remote telecom systems, up to $250 \mathrm{~kW}$ and higher in large telecom centers. The designed power plant in this paper has the power rating of $22.5 \mathrm{~kW}$. This topology can easily be applied to other telecom systems by changing the size of fuel cell and micro-turbine accordingly.

\section{MULTIPLE INPUT BUCK-BOOST CONVERTER}

The designed topology uses a multiple input positive buck-boost (MIPBB) converter to connect all the micro-sources to the main DC bus. Multiple input converters can combine different energy sources with different current and voltage characteristic [7] with less number of parts. There are many different multiple input converters available. Some of the benefits of the proposed MIPBB converter are low number of parts and positive output voltage without requiring any extra transformer.

Fig. 3 shows the proposed MIBB converter. This converter uses one common inductor and one capacitor for all of the inputs. Besides, another benefit of this converter is that it can accommodate up to $\mathrm{N}$ different inputs with $\mathrm{N}$ different voltage and current characteristics. This converter can be used as a buck or buck-boost converter. Here, the buck-boost operation is chosen since voltage of micro-turbine is higher the output and voltage of fuel cell is lower than output. In order to drive this converter in buck-boost mode $8 \mathrm{j}(\mathrm{i}=1,2, \ldots, \mathrm{N})$ and $\mathrm{Qj}$ should be switching at the same time.

In this paper, FC and MT are chosen as two micro-sources. The proposed converter is used as a two input converter. Generally, if another micro-source is added to the system, same topology can be applied by adding one more switch.

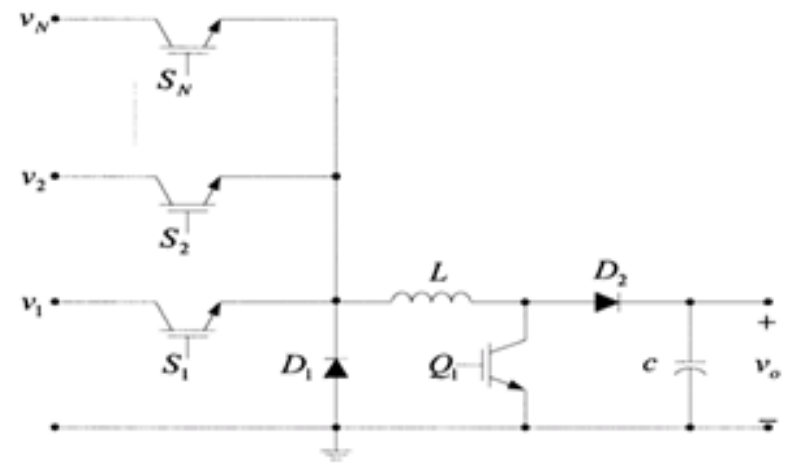

Fig.3.The proposed multi-input positive buck-boost converter

There are three different modes of operation for two input buck-boost converter. Switch Qis ON whenever one or more of the input switches are ON. Inputs are ordered from low voltage to high voltage $(\mathrm{Vj}<\mathrm{V} 2)$. In first mode both $8 \mathrm{j}$ and 82 are $\mathrm{ON}$. In this mode the input with higher voltage turns OFF the other switch. Hence, in mode 1the input with higher voltage (V2) is conducting. In second mode, switch 82 turns OFF therefore in this mode, the lower voltage input $(\mathrm{Vj})$ is conducting. In mode 3 , both $8 \mathrm{j}$ and 82 are turned $\mathrm{OFF}$ and in this mode $\mathrm{Dj}$ and D2 are turned ON. With this switching strategy each switch has a duty cycle and an effective duty cycle. For 82 the duty cycle and effective duty cycle are the same while for $8 \mathrm{j}$ the effective duty cycle is;

$$
D_{\text {eff }(1)=D_{1}-D_{2}}
$$

Based on Eq. (I) D1 should be greater than D2 to be able to transfer power from first input to the output. If the number of inputs is increased to more than two, the equation for effective duty cycle becomes;

$$
D_{e f f(i)}=D_{i}-\sum_{i+1}^{N} D_{e f f(j)}
$$




\section{MODELING FUEL CELL AND MICRO-TURBINE}

The dynamic modeling principles of the FC and MT are presented in this section.

A. Fuel Cell Model

Fuel cells are known to have higher efficiency than conventional power plants [8]. Fuel cells are environmentally friendly (environmentally clean), have extremely low emission and they produce very low noise [8]. Fuel cells are composed of fuel processing unit (reformer), the fuel cell stack, and a power conditioning unit [10]. Hydrogen is produced in the reformer by processing any hydrocarbon fuel [8]. Some examples of hydrocarbon fuels are propane, methane, and methanol. The produced hydrogen is supplied to the fuel cell stack. Using provided hydrogen, and oxygen from the air; and through the electrochemical process, fuel cell stack produces electricity and water. Due to low operating temperature and rapid start up time, Proton Exchange Membrane Fuel Cell Power Plants (PEM FCPPs) are typically the best candidate for telecommunication power systems. A model for $27 \mathrm{~kW}$ (PEM FCPPs) is developed. The fuel cell model that is used in this paper is developed in MATLAB \& Simulink. Then, this model is implemented in Power System as a controlled voltage source [8] and [9]. The fuel cell parameters are presented in Table 1.

The relationship between the modular flows of any gas through the valve is proportional to its partial pressure inside the channel [11]. For hydrogen, this relationship can be expressed as follows

$\frac{q_{H 2}}{p_{h 2}}=\frac{K_{a n}}{\sqrt{M_{H 2}}}$

The molar flow of hydrogen that reacts can be found from the basic electrochemical relationship between hydrogen flow and the fuel cell system current [9]

$q^{r}{ }_{H}=\frac{N_{0} N_{\text {Stack }} I_{F C}^{i}}{2 F}=2 K_{r} I_{F C}^{i}$

The hydrogen partial pressure can be obtained by applying Laplace transform on (3) and (4) [9],

$$
P_{H 2}=\frac{1 / K_{H 2}}{1+T_{H 2}}\left(q_{H 2}^{i n}-2 K_{r} I_{F C}^{i}\right)
$$

Where

$T_{H 2}=\frac{V_{a n}}{K_{H 2} R T}$

Similar operation can be done for water and oxygen partial pressure. The Nernst's instantaneous voltage can be expressed as eq. (7) [12].

$E=N_{0} N_{\text {stack }}\left[E_{0}+\frac{R T}{2 F} \log \left[\frac{P_{H 2} \sqrt{P_{O S}}}{P_{H 20}}\right]\right]$

The reformer generates hydrogen for stack operation of fuel cell. The fuel cell system consumes hydrogen based on the power demand. Mathematical equation of the reformer model can be expressed as [9]

$\frac{q_{H 2}^{i n}}{q_{\text {ment hol }}}=\frac{C V}{T_{1} T_{2} s^{2}+\left(T_{1}+T_{2}\right) s+1}$

which describes the relationship between the input gas methanol and the produced hydrogen.

TABLE 1.Fuel Cell Parameters

\begin{tabular}{|c|c|}
\hline $\mathrm{B}, \mathrm{C}$ & $\begin{array}{l}\text { Constant to simulate the activation over voltage in } \\
\text { PEM FCPP system [v] }\end{array}$ \\
\hline $\mathrm{CV}$ & $\begin{array}{l}\text { Conversion factor [kmol of hydrogenper per } \mathrm{kmol} \\
\text { of methane] }\end{array}$ \\
\hline $\mathrm{E}$ & Nerst instantaneous voltage [V] \\
\hline $\mathrm{E}_{0}$ & Standard no load voltage $[\mathrm{V}]$ \\
\hline $\mathrm{F}$ & Faraday's constant $[\mathrm{C} / \mathrm{kmol}]$ \\
\hline $\mathrm{I}_{\mathrm{FC}}$ & Fuel cell system feedback current $[\mathrm{A}]$ \\
\hline $\mathrm{K}_{1}$ & Proportional - integral (PI )gain \\
\hline $\mathrm{K}_{\mathrm{an}}$ & Anode valve constant $\left[\sqrt{\mathrm{kmol} . \mathrm{Kg}(\mathrm{atm} . \mathrm{s})^{-1}}\right]$ \\
\hline $\mathrm{KH}_{2}$ & Hydrogen valve molar constant $[\mathrm{kmol} /(\mathrm{atm} . \mathrm{s})]$ \\
\hline $\mathrm{KH}_{2 \mathrm{O}}$ & Water valve molar constant $[\mathrm{kmol} /(\mathrm{atm} . \mathrm{s})]$ \\
\hline $\mathrm{K}_{\mathrm{O} 2}$ & Oxygen valve molar constant $[\mathrm{kmol} /(\mathrm{atm} . \mathrm{s})]$ \\
\hline $\mathrm{K}_{\mathrm{r}}$ & Modeling constant $[\mathrm{kmol} /(\mathrm{s} . \mathrm{A})$ \\
\hline $\mathrm{M}_{\mathrm{H} 2}$ & Molar mass of hydrogen [Kg.kmol $\left.{ }^{-1}\right]$ \\
\hline
\end{tabular}




\begin{tabular}{|c|c|}
\hline $\mathrm{N}_{\mathrm{O}}$ & Number of series fuel cell in stack \\
\hline $\mathrm{N}_{\text {stack }}$ & Number of stacks \\
\hline $\mathrm{PH}_{2}$ & Hydrogen partial pressure [atm] \\
\hline $\mathrm{PH}_{2 \mathrm{O}}$ & Water partial pressure [atm] \\
\hline $\mathrm{PO}_{2}$ & Oxygen partial pressure [atm] \\
\hline $\mathrm{qH}_{2}$ & Molar flow of hydrogen $[\mathrm{kmol} / \mathrm{s}]$ \\
\hline $\mathrm{qO}_{2}$ & Input molar flow of oxygen $[\mathrm{kmol} / \mathrm{s}]$ \\
\hline $\mathrm{q}_{\text {methanol }}$ & Methanol flow rate $[\mathrm{kmol} / \mathrm{s}]$ \\
\hline $\mathrm{q}^{\mathrm{in}} \mathrm{H} 2$ & Hydrogen input flow [kmol/s] \\
\hline $\mathrm{q}^{\text {out }}{ }_{\mathrm{H} 2}$ & Hydrogen output flow [kmol/s] \\
\hline $\mathrm{q}_{\mathrm{H} 2}^{\mathrm{r}}$ & Hydrogen flow that reacts $[\mathrm{kmol} / \mathrm{s}]$ \\
\hline $\mathrm{q}_{\mathrm{H} 2}^{\mathrm{req}}$ & $\begin{array}{l}\text { Amount of hydrogen flow required to meet the } \\
\text { load change }[\mathrm{kmol} / \mathrm{s}]\end{array}$ \\
\hline $\mathrm{R}$ & Universal gas constant $[(1$ atom $) /(\mathrm{kmol} . \mathrm{k}]$ \\
\hline $\mathrm{R}^{\mathrm{int}}$ & Fuel cell internal resistance $[\Omega]$ \\
\hline $\mathrm{T}$ & Absolute temperature[K] \\
\hline $\mathrm{U}$ & Utilization rate \\
\hline $\mathrm{V}_{\mathrm{an}}$ & Volume of the anode $\left[\mathrm{M}^{3}\right]$ \\
\hline $\mathrm{V}_{\text {cell }}$ & DC output voltage of fuel cell system [V] \\
\hline$\Gamma_{2}$ & Reformer time constant $[\mathrm{s}]$ \\
\hline$\Gamma_{3}$ & Time constant of the PI controller [s] \\
\hline$\left\lceil\mathrm{H}_{2}\right.$ & Hydrogen time constant $[\mathrm{s}]$ \\
\hline $\mathrm{\Gamma o}_{2}$ & Oxygen time constant $[\mathrm{s}]$ \\
\hline $\mathrm{IH}_{2 \mathrm{O}}$ & Water time constant $[\mathrm{s}]$ \\
\hline$\eta_{\text {act }}$ & Activation over voltage [V] \\
\hline$\eta_{\text {ohmic }}$ & Ohmic over voltage [V] \\
\hline $\bar{\Gamma}$ & Fuel cell constant \\
\hline
\end{tabular}

Assuming constant temperature and oxygen concentration, the fuel cell output voltage can be obtained from the sum of Nemst's voltage, the activation over voltage and the ohmic over voltage [9],

$V_{\text {cell }}=E-n_{\text {act }}-n_{\text {ohmic }}$

Where

$n_{\text {act }}=B \operatorname{In}\left(C l_{F C}\right)$

And

$n_{\text {ohmic }}=R^{\text {int }} I_{F C}$

Based on Eqs. (3) to (11), the developed model for fuel cell is shown in Fig. 4.

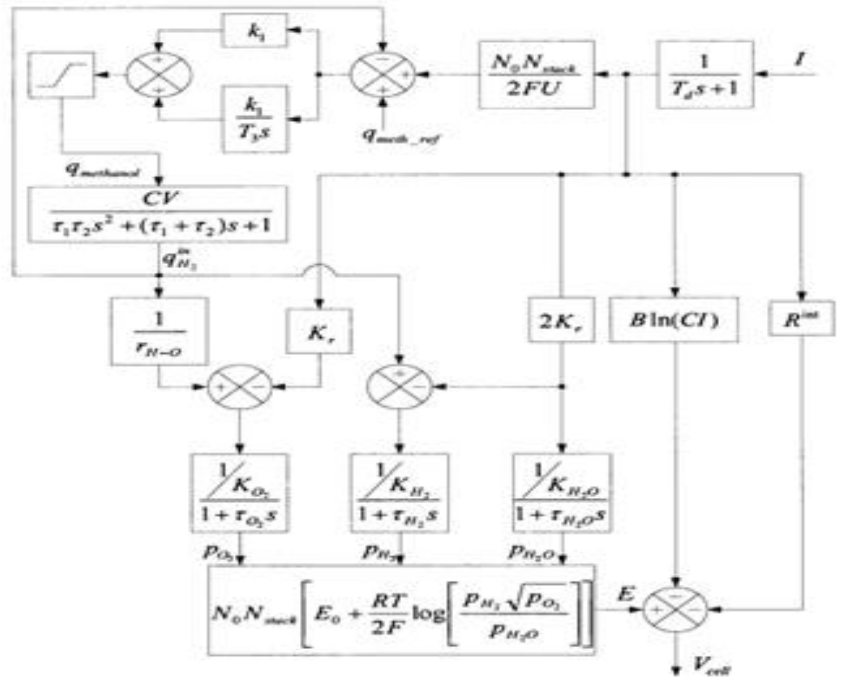

Fig.4.Fuel cell model 
The fuel cell that is modeled here is a $48 \mathrm{~V}, 27 \mathrm{~kW}$, PEM fuel cell. Each cell has the voltage of $0.8 \mathrm{~V}$ and each stack in fuel cell has a current capacity of 94A. The fuel cell model consists of six parallel stacks and each stack has 88 cells in series. The fuel cell parameter values are given in Table 2.

Peak current mode control is chosen to control the power flow from Fe. Typically, peak current mode control does not let the peak current goes beyond a certain set point [15]. Fig. 5 shows a typical peak current mode control.

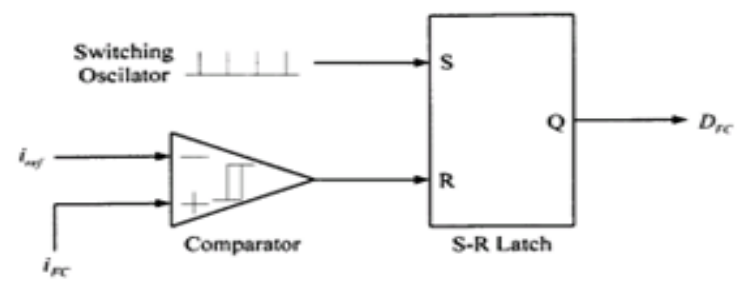

Fig.5.peak current mode control

TABLE 2.PEM FCPP Parameters

\begin{tabular}{|c|c|}
\hline PARAMETER & VALUE \\
\hline Stack temperature & $343[\mathrm{~K}]$ \\
\hline Faraday's constant $(\mathrm{F})$ & $96484600[\mathrm{C} / \mathrm{kmol}]$ \\
\hline Universal gas constant (R) & $8314.47[\mathrm{j} /(\mathrm{lmolK})]$ \\
\hline No load cell voltage $\left(\mathrm{E}_{\mathrm{O}}\right)$ & $0.8[\mathrm{~V}]$ \\
\hline Number of cell per stack $\left(\mathrm{N}_{\mathrm{O}}\right)$ & 88 \\
\hline Number of stacks $\left(\mathrm{N}_{\text {stack }}\right)$ & 6 \\
\hline $\mathrm{K}_{\mathrm{r}}$ Constant & $1.4251^{*} 10^{-6[\mathrm{kmol} /(\mathrm{Sa})]}$ \\
\hline Utilization factor (U) & 0.8 \\
\hline Hydrogen valve constant $\left(\mathrm{KH}_{2}\right)$ & $4.22 * 10^{-5}[\mathrm{kmol} /(\mathrm{s} \mathrm{atm})]$ \\
\hline Water valve constant $\left(\mathrm{KH}_{2 \mathrm{O}}\right)$ & $7.716 * 10^{-6}[\mathrm{kmol} /(\mathrm{s} \mathrm{atm})]$ \\
\hline Oxygen valve constant $\left(\mathrm{Ko}_{2}\right)$ & $2.11 * 10^{-5}[\mathrm{kmol} /(\mathrm{s} \mathrm{atm})]$ \\
\hline Hydrogen time constant $\left(\mathrm{rH}_{2}\right)$ & $3.37[\mathrm{~s}]$ \\
\hline Water time constant $\left(\mathrm{rH}_{2 \mathrm{O}}\right)$ & $18.418[\mathrm{~s}]$ \\
\hline Oxygen time constant $\left(\mathrm{Io}_{2}\right)$ & $6.74[\mathrm{~s}]$ \\
\hline Reformer time constant $\left(\Gamma_{1}\right)$ & $2[\mathrm{~s}]$ \\
\hline Reformer time constant $\left(\Gamma_{2}\right)$ & $2[\mathrm{~s}]$ \\
\hline Reformer PI gain $\left(\mathrm{C}_{1}\right)$ & 0.25 \\
\hline Conversion factor (CV) & 2 \\
\hline Activation voltage constant (B) & $0.04777\left[\mathrm{~A}^{-1}\right]$ \\
\hline Activation voltage constant (C) & $0.0136[\mathrm{~V}]$ \\
\hline Internal resistance $\left(\mathrm{R}^{\mathrm{int}}\right)$ & $0.2778[\Omega]$ \\
\hline External line reactance $(\mathrm{X})$ & $0.05[\Omega]$ \\
\hline PI gain constant $\left(\mathrm{C}_{1}, \mathrm{C}_{2}\right)$ & $0.1,10$ \\
\hline Voltage reference signal $\left(\mathrm{V}_{\mathrm{r}}\right)$ & 1.0 [p.u] \\
\hline Methane reference signal $\left(\mathrm{Q}_{\text {meth-ref }}\right)$ & $0.000015[\mathrm{lmol} / \mathrm{s}]$ \\
\hline Hydrogen - oxygen flow ratio $\left(\mathrm{r}_{\mathrm{H}-\mathrm{O}}\right)$ & 1.168 \\
\hline Current delay time constant $\left(\mathrm{T}_{\mathrm{d}}\right)$ & $3[\mathrm{~s}]$ \\
\hline
\end{tabular}

B. Micro-Turbine Model

The operation principles of a micro-turbine are similar to a steam turbine. Compressor, combustion chamber, and a turbine are the three main components of a micro-turbine. The air after being compressed in compressor forms a combustible mixture by getting mixed with the injected fuel. The mixture is ignited in combustor to produce heated air. Then the heated air is expanded in turbine to drive the turbine [8]. There are two major types of micro-turbine; single shaft and split shaft [13]. In single shaft micro-turbine electric generator and turbine are mounted in same shaft. In split shaft micro-turbine, a gear box is used to couple the electric generator to the micro-turbine. Model is developed for a $37 \mathrm{~kW}, 300 \mathrm{~V}$ micro-turbine [8]. Fig. 6 (a) shows a single shaft micro-turbine. In single shaft micro-turbine compressor, turbine, and electric generator are all on the same shaft. The turbine speed is in the range of 50,000 to $120,000 \mathrm{rpm}$. The frequency of produced 
voltage is in the range of 1500 to $4000 \mathrm{~Hz}$ [8]. A cyclo converter is required to reduce the frequency to $60 \mathrm{~Hz}$. In split shaft model, the generator shaft is connected to turbine shaft through a gear box. The gear box is used to reduce the generator speed to $3600 \mathrm{rpm}$. If the synchronous generator has two poles, the frequency will be $60 \mathrm{~Hz}$ and there is no need for a cyclo-converter.

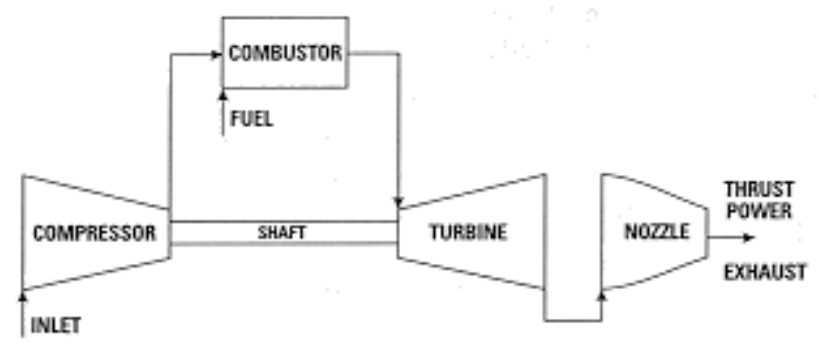

Fig. 5.2 (a) Single shaft micro-turbine schematic

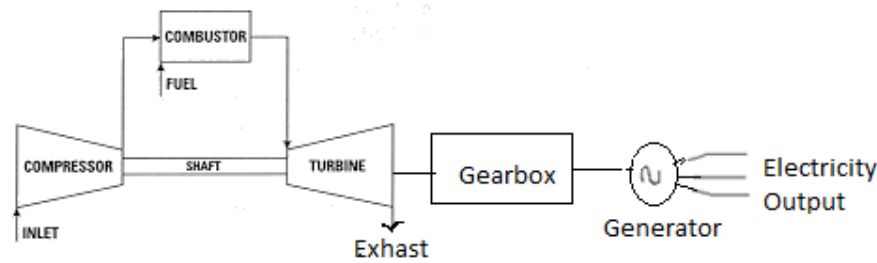

Fig. 5.2 (b) Split shaft Micro-turbine schematic.

A split shaft micro-turbine is modeled based on the principle explained in [8]. In order to model the micro-turbine, synchronous generator with speed and power controller is used. A simplified synchronous machine model of Power System is utilized as a synchronous generator driven by the mechanical power produced by the turbine model. The synchronous machine model parameters are given in Table 3 .

TABLE 3.Synchronous Machine Parameters

\begin{tabular}{|l|l|}
\hline \multicolumn{1}{|c|}{ PARAMTER } & \multicolumn{1}{c|}{ VALUE } \\
\hline Rated power $\left(\mathrm{P}_{\text {rated-SG }}\right)$ & $37.5[\mathrm{KW}]$ \\
\hline Rated line to line voltage $\left(\mathrm{V}_{\text {rated }}\right)$ & $300[\mathrm{~V}]$ \\
\hline Frequency $(\mathrm{F})$ & $60\left[\mathrm{H}_{\mathrm{Z}}\right]$ \\
\hline Inertia constant $(\mathrm{H})$ & $0.22[\mathrm{~S}]$ \\
\hline Damping factor $\left(\mathrm{K}_{\mathrm{D}}\right)$ & $33.63[\mathrm{p} . \mathrm{u}]$ \\
\hline Number of poles $(\mathrm{P})$ & 2 \\
\hline Internal resistance $(\mathrm{R})$ & $0.0428[\mathrm{p} . \mathrm{u}]$ \\
\hline Internal reactance $(\mathrm{X})$ & $0.0778[\mathrm{p} . \mathrm{u}]$ \\
\hline
\end{tabular}

Three controllers (speed, power, and load controls) are used to control the synchronous machine for its operation as a micro-turbine. The speed controller is defined by,

$w_{\text {in }}=\left(w_{\text {ref }}-w_{r}\right)\left[K_{s}+\frac{K_{K}}{s}\right]$

The power controller is defined by,

$P_{\text {in }}=\left(P_{\text {ref }}-P_{r}\right)\left[K_{F}+\frac{K_{i}}{s}\right]$

Finally, the load controller is defined by,

$L_{\text {in }}=\left[L_{\text {max }}-P_{1} \frac{1}{1+T_{3} s}\right] K_{T}+L_{\max }$

The minimum of $w_{i n}, P_{i n}$ and $L_{i n}$ is defined as $\mathrm{C}_{\mathrm{v}}$ which is the output of a Low Value Gate (LVG) in the proposed model as

$C_{v}=\min \left\{w_{\text {in }}, P_{\text {in }}, L_{\text {in }}\right\}$

The mechanical input power is,

$P_{\text {in }}=P_{1}-w_{r} D_{\text {turbine }}$

Where

$P_{1}=C_{v} \frac{1}{T_{1} T_{2} s^{2}+\left(T_{1}+T_{2}\right) s+1}$ 
$P_{1}$ is limited by the minimum and maximum valve position. Micro-turbine model parameters can be found in Table 4.

TABLE 4.Micro-Turbine Model Parameters

\begin{tabular}{|l|l|}
\hline \multicolumn{1}{|c|}{ PARAMTER } & VALUE \\
\hline Rated power $\left(\mathrm{P}_{\text {rated-MT }}\right)$ & $37.5 \mathrm{KW}$ \\
\hline Real power reference $\left(\mathrm{P}_{\text {ref }}\right)$ & $1.0[\mathrm{p} . \mathrm{u}]$ \\
\hline Turbine damping $\left(\mathrm{D}_{\text {turbine }}\right)$ & 0.03 \\
\hline Fuel system lag time constant $\left(\mathrm{T}_{1}\right)$ & $10.0[\mathrm{~s}]$ \\
\hline Fuel system lag time constant $\left(\mathrm{T}_{2}\right)$ & $0.1[\mathrm{~s}]$ \\
\hline Load limit time constant $\left(\mathrm{T}_{3}\right)$ & $3.0[\mathrm{~s}]$ \\
\hline Load limit $\left(\mathrm{L}_{\max }\right)$ & 1.2 \\
\hline Maximum value position $\left(\mathrm{V}_{\max }\right)$ & 1.2 \\
\hline Minimum valve position $\left(\mathrm{V}_{\min }\right)$ & -0.1 \\
\hline Temperature control loop constant $\left(\mathrm{K}_{\mathrm{T}}\right)$ & 1.0 \\
\hline Power control proportional gain $\left(\mathrm{K}_{\mathrm{F}}\right)$ & 0.1 \\
\hline Power control integral gain $\left(\mathrm{K}_{\mathrm{i}}\right)$ & 1.0 \\
\hline Speed control proportional gain $\left(\mathrm{K}_{\mathrm{S}}\right)$ & 1000 \\
\hline Speed control integral gain $\left(\mathrm{K}_{\mathrm{K}}\right)$ & 12.5 \\
\hline Speed reference $\left(\omega_{\text {ref }}\right)$ & $1.0[\mathrm{p} . \mathrm{u}]$ \\
\hline
\end{tabular}

The block diagram for speed, power and load control employed in the MT model is illustrated in Fig. 7.

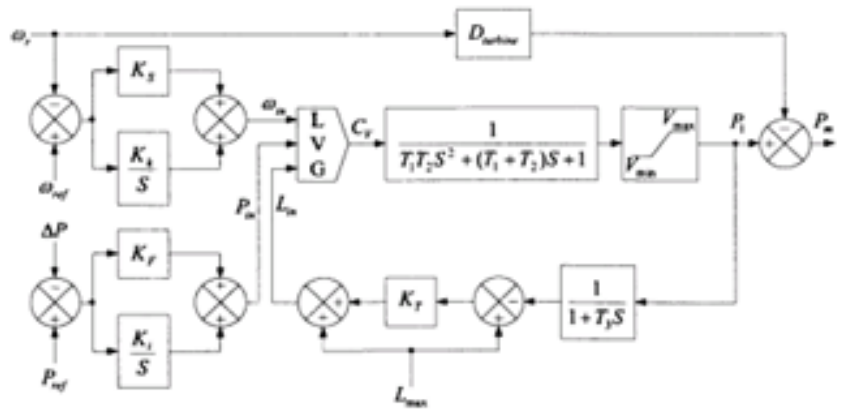

Fig.7.Block diagram for speed, power and load control of the MT

Additionally, excitation voltage control is used in the micro-turbine model in order to keep the synchronous generator output voltage within a reasonable band. In this control, the measured and reference phase to phase voltage values of the generator voltage is compared. The difference is then processed through a PI controller which determines the excitation voltage to be applied to the generator.

\section{RESULTS}

The overall system configuration is demonstrated in Fig. 8.

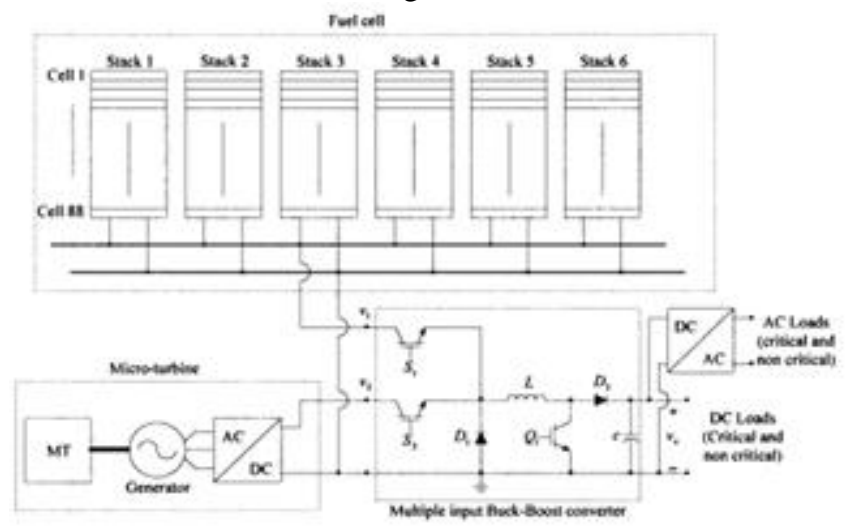

Fig.8. Overall system configuration

Fuel cell (Fe) and micro-turbine (MT) are used as two input sources for the multiple input positive buck-boost (MIPBB) converters. The inductance of MIPBB converter is $2 \mathrm{flH}$ and the capacitance is $5 \mathrm{mF}$. The switching 
frequency is $50 \mathrm{kHz}$. In order to analyze the dynamic behavior of the system, step changes in load variations are investigated. This system is designed for the load of $22.5 \mathrm{~kW}$. At the time of step load change, the output load is increased to $33.6 \mathrm{~kW}$ at time $0.3 \mathrm{~s}$ (increases about $50 \%$ of demanding power) and reduced to $11.25 \mathrm{~kW}$ at time $0.7 \mathrm{~s}$ (decrease about $50 \%$ of demanding power).

Figs. 9 and 10 show the voltage and current of fuel cell respectively. When the load increases, the voltage of fuel cell is dropped about 2 volts and the current of fuel cell is increased to provide more power to the load.

Fig. $11 \& 12$ shows the voltage and current of micro-turbine. When the load increases, the current of microturbine is increased instantly to provide the extra demanding power at the load. Again, when the load decreases, the current of micro-turbine is decreased to compensate the less power that is needed at the load bus.

Fig. 13 and 14 shows the voltage and current at the DC bus respectively. The voltage at DC bus is regulated at $150 \mathrm{~V}$ : In transient conditions such as step change In load, there IS a very small oscillation in voltage. This figure shows the robustness and effectiveness of the voltage mode controller that is used. In transient condition, there is no voltage drop or increase at the DC bus and the only change is in the current of DC bus.

Fig. 15 shows the power of FC, MT, and output power respectively. Initially, when the demanding power is $22 . .5 \mathrm{~kW}, 9.5 \mathrm{~kW}$ of this power (about $42 \%$ of the power) IS supplied by FC and the rest (about $13.75 \mathrm{~kW}$ ) f demanding power is supported by MT. When the demanding power IS increased to $33.6 \mathrm{~kW}, 12 \mathrm{~kW}$ of this power (about $36 \%$ of the power) is supplied by FC and $22.25 \mathrm{~kW}$ is supported by MT. When the demanding power is decreased to $11.25 \mathrm{~kW}, 6.65 \mathrm{~kW}$ of this power (about $59 \%$ of the power) is supplied by FC and $4.7 \mathrm{~kW}$ is supported by MT. This figure shows how the output power is shared between the FC and MT.

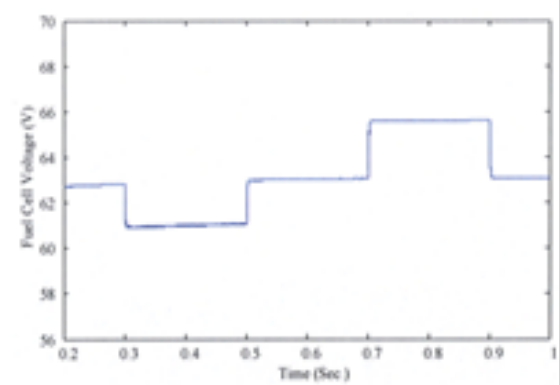

Fig.9.Fuel Cell voltage

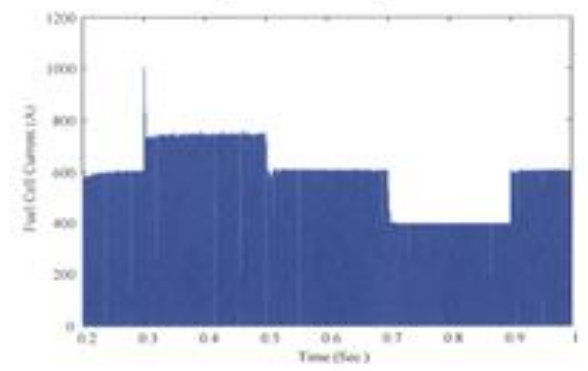

Fig.10.Fuel Cell current

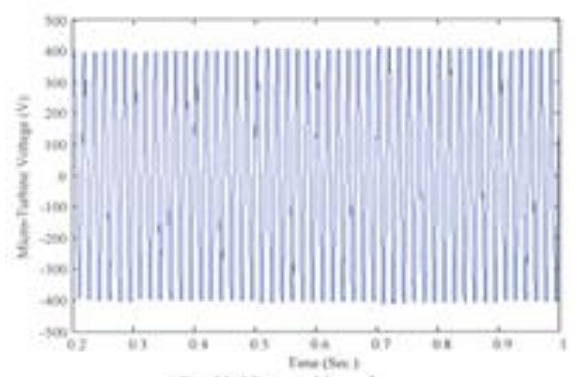

Fig.11.Micro Turbine voltage 


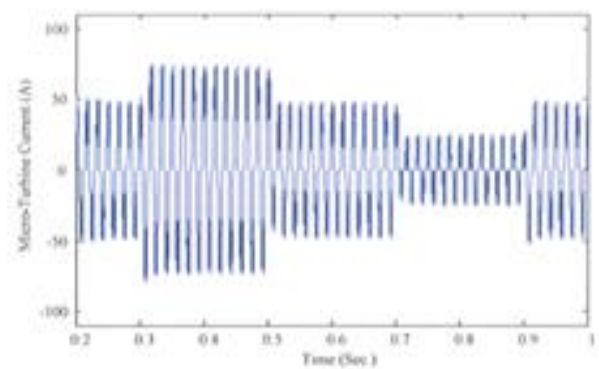

Fig.12.Micro Turbine current

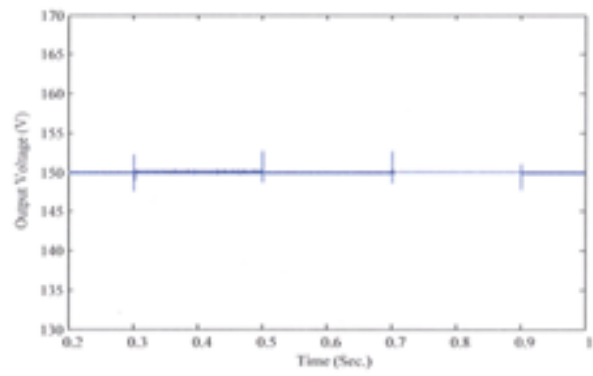

Fig.13.Output voltage

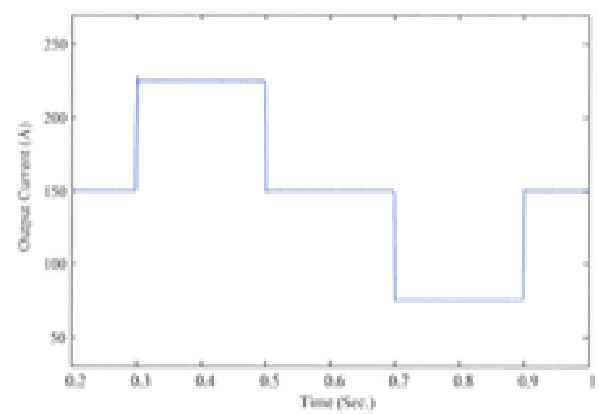

Fig.14.Output current

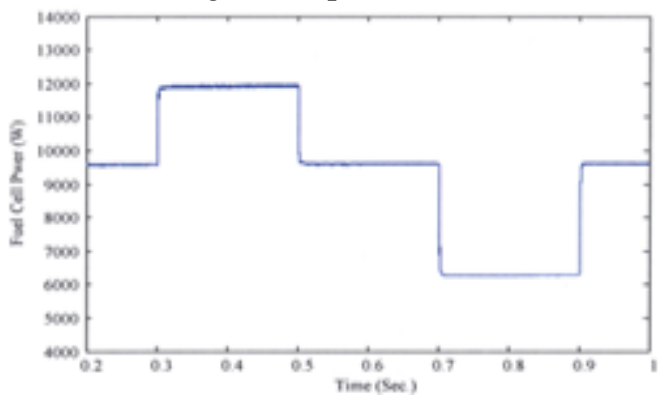

Fig.15.Fuel Cell power

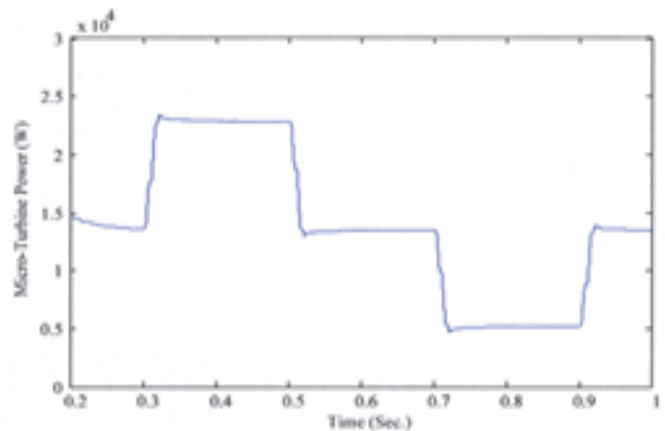

Fig.16.Micro Turbine power 


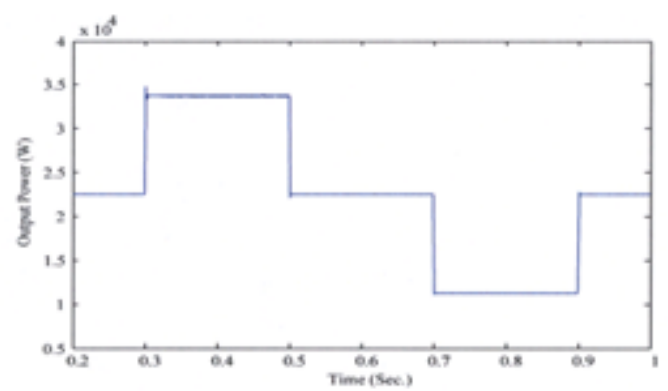

Fig.17.Output power

\section{CONCLUSIONS}

A new topology for telecom power system is introduced in this paper. The new system was primarily powered by micro-sources, i.e. MT and FC. The new topology has the advantages of eliminating batteries, diesel generator, and transfer switch. Modeling of PEM FC and MT was described. Also a novel multiple input positive buck- boost converter was introduced. This converter can connect multiple inputs with different voltage and current characteristic to a single output. Detailed analytical and mathematical modeling, design, and analysis are presented. According to the results, the system presented an excellent response in meeting the power requirements of a telecom system. Two control modes used for the multiple input buck-boost converter is also tested and results showed the effectiveness and the success of the system. Dynamic behavior of the proposed topology for load transients demonstrated. Presented results show that the proposed topology is an enabling technology for future telecom power systems.

\section{REFERENCES}

[1] M. Fraisse and L. Buchsbaum, "Environment friendly high quality, high availability telecom power plant architecture," International Telecommunication Energy Conference, 2002, pp. 463-469.

[2] W. Allen and S. Natale, "Achieving ultra-high system availability in a battery-less -48Vdc power plant," International Telecommunication Energy Conference, 2002, pp. 287-294.

[3] B. Maher, "High reliability backup for telecommunications using ultracapacitors," International Telecommunication Energy Conference, 2004, pp. 623-625.

[4] M. Perry and S. Kotso, "A back-up power solution with no batteries," International Telecommunication Energy Conf., 2004, pp. 210-217.

[5] A. Kwasinski and P. Krein, "A microgrid-based telecom power system using modular multiple-input dcdc converters," International Telecommunication Energy Conference, 2005, pp. 515-520.

[6] A. F. Massardo, C. F. McDonald and T. Korakianitis, "Microturbine/fuel-cell coupling for highefficiency electrical power generation," Transaction ofthe ASME, vol. 124, Jan. 2002, pp.110-116.

[7] A. Khaligh, "A multiple-input dc-dc positive buck-boost converter topology," in Proc. IEEE Applied Power Electronics Conference, Austin, TX, Feb. 2008.

[8] M. Uzunoglu, O. Onar, M. Y. EL-Sharkh, N. S. Sisworahardjo, A. Rahman, and M. S. Alam, "Parallel operation characteristics of PEM fuel cell and microturbine power plants," Journal of power sources, vol. 168, no. 2, 2007, pp. 469-476.

[9] M. Uzunoglu and M. S. Alam, "Dynamic modeling, design, and simulation of a combined PEM fuel cell and ultracapacitor system for stand-alone residential applications," IEEE Transactions on Energy Conversion, vol. 21, no. 3, Sept. 2006, pp. 767-775.

[10] 1. E. Larmine and A. Dicks, Fuel cell systems explained, second edition, John Wiley and sons, 2000.

[11] M. Y. EL-Sharkh, A. Rahman, M. S. Alam, P. C. Byrne, A. A. Sakla, and T. Thomas, "A dynamic model for a stand-alone PEM fuel cell power plant for residential application," Journal ofpower sources, vol. 138,2004,pp.199-204.

[12] 1.Padulles,G.W.Ault, and J. R. McDonald, "An integrated SOFC plant dynamic model for power systems simulation," Journal of Power Sources, vol. 86, 2000, pp. 495-500.

[13] Y.Zhu and K.Tomsovic,"Development of models for analyzing the load-flowing performance of microturbines and fuel cell," Electric Power System Research, vol. 62, 2002.

[14] M. Nagpal, A. Moshref, G. K. Morison, and P. Kundur, "Experience with testing and modeling of gas turbines," Power Engineering Society Winter Meeting, vol. 2, 2001, pp. 652-656.

[15] P. T. Krein, Elements of Power Electronics, Oxford university press, 1998. 